\title{
Article
}

http://dx.doi.org/10.11646/phytotaxa.172.2.1

\section{A new subspecies of Rosmarinus officinalis (Lamiaceae) from the eastern sector of the Iberian Peninsula}

\author{
P. PABLO FERRER-GALLEGO ${ }^{1}$, RAÚl FERRER-GALLEGO ${ }^{2}$, ROBERTO ROSELLÓ ${ }^{3}$, JUAN B. PERIS ${ }^{4}$, \\ ALBERTO GUILLÉN ${ }^{4}$, JOSÉ GÓMEZ ${ }^{5} \&$ EMILIO LAGUNA ${ }^{1}$ \\ ${ }^{I}$ Servicio de Vida Silvestre. Centro para la Investigación y Experimentación Forestal (CIEF). Conselleria d'Infraestructures, Territori i \\ Medi Ambient. Generalitat Valenciana. Avda. Comarques del País Valencià, 114. E-46930.Quart de Poblet.València.flora.cief@gva.es \\ ${ }^{2}$ Grupo de Investigación en Polifenoles. Unidad de Nutrición y Bromatología, Facultad de Farmacia, Universidad de Salamanca, \\ Campus Miguel de Unamuno, E 37007 Salamanca, Spain.rauferga@usal.es \\ ${ }^{3}$ IES Jaume I, Plaça Sanchis Guarner s/n, E-12530 Borriana, Castelló, España.rrosello514@cv.gva.es \\ ${ }^{4}$ Departament de Botànica. Facultat de Farmacia. Universitat de València. Avda. Dr. Moliner, 50, E-46100, Burjassot, València. \\ jbperis@uv.es \\ ${ }^{5}$ Instituto Botánico, Sección de Sistemática y Etnobotánica. Universidad de Castilla-La Mancha, Avenida de La Mancha s/n, E-02071, \\ Albacete.jgon0141@yahoo.es
}

\begin{abstract}
Rosmarinus officinalis subsp. valentinus (Lamiaceae) is described as a new subspecies in the flora of the Iberian Peninsula. The diagnostic characters for the subsp. valentinus include several morphological differences, mainly based on a distinctly prostrate habit, a reduced leaf size, smaller calyx and corolla, and white flower. A comparative table with diagnostic morphological features to distinguish among the three subspecies of the $R$. officinalis is provided. Habitat, ecology, greenhouse cultivation and phenolic profile are also considered.
\end{abstract}

Key words: Lamiaceae, Mediterranean area, phenolic compounds, Rosmarinus officinalis, taxonomy

\section{Introduction}

In the Iberian flora the genus Rosmarinus Linnaeus (1753:23) is composed of three species and two hybrids (Rosúa 1981: 587; Morales 2010: 328): $R$. officinalis L., $R$. eriocalix Jord. \& Fourr., $R$. tomentosus Hub.-Mor. \& Maire, $R$. $\times$ lavandulaceus De Noé $(R$. eriocalix $\times R$. officinalis) and $R$. $\times$ mendizabalii Sagredo ex Rosúa $(R$. officinalis $\times R$. tomentosus).

Rosmarinus is frequently found in open formations and is one of the most common species in scrubland and the arboreal stratum. Rosmarinus tomentosus is endemic in the south of Spain (Granada and Malaga); R. eriocalix is distributed in North Africa (Morocco, Algeria and Libya) and Almeria (south of Spain) and R. officinalis is widespread and mainly distributed in the western half of the Mediterranean area, between Europe and North Africa, although it is almost absent in the eastern Mediterranean basin.

The high genetic variability of $R$. officinalis and its ecological plasticity, as well as its coexistence with the other two species of the genus in the southeast, suggest that its focus of diversification is located in this territory (MateuAndrés et al. 2013). The studies of Zaouali \& Boussard (2008) reported a correlation between the allozyme genetic variability and the structure and composition of the essential oils. The biochemical variability is well characterized by chemotypes (Rosúa \& García Granados 1987; Garbarino et al. 2006; Boelens 1985). Analyses of nuclear microsatellites have also been used to confirm certain genetic variability in the species (Segarra-Moragués \& Gleiser 2009). However, other authors have described a relatively low genetic variability (Rosselló et al. 2006). Morphologically, $R$. officinalis consists of a broad range of varieties, forms, races and ecotypes (Turril 1920: 105).

A large amount of phenolic compounds has been found in several species of the Lamiaceae (Ziaková \& Brandsteterová 2003; Barros et al. 2013; Kontogianni et al. 2013). The characterization of these compounds in this family has been studied in depth, with reports of differences among species in their phenolic profiles (Valant-Vetschera et al. 2003; Hossain et al. 2010). 


\section{Acknowledgements}

Thanks to the curators of BC, MA and VAL for their assistance. Thanks are also given to N. Skinner (University of Salamanca, Spain) for revising the English version of the manuscript.

\section{References}

Amaral Franco J. \& Rocha Alonso M.L. (1973) Rosmarinus L. In: T. G. Tutin et al. (eds.) Flora Europaea 3: 187. Cambridge University Press, Cambridge.

Barros L., Dueñas M., Dias M.I., Sousa M.J., Santos-Buelga C., Ferreira I. (2013) Phenolic profiles of cultivated, in vitro cultured and commercial samples of Melissa officinalis L. infusions. Food Chemistry 132: 841-848.

http://dx.doi.org/10.1016/j.foodchem.2012.07.107

Boelens M.H. (1985) The essential oil from Rosmarinus officinalis L. Perfumer \& Flavorist 10: 21-37.

Bolòs, O. \& Moliner R. (1958) Recherches phytosociologiques dans l'Île de Majorque. Collect. Bot. (Barcelona) 5(3): 699-865.

Bolòs, O. \& Vigo J. (1996) Flora dels Països Catalans. Vol. 3. Barcino. Barcelona.

Bolòs O., Vigo J., Masalles R.M. \& Ninot J. M. (2005) Flora manual dels Països Catalans. $3^{\text {a }}$ ed. Pòrtic, Barcelona.

Crespo, M.B. (2001) Ajustes nomenclaturales en matorrales iberolevantinos de Rosmarinetea. Flora Montiberica 18: 1-4.

De la Torre, A., Alcaraz, F. \& Crespo, M. B. (1996) Aproximación a la biogeografía del sector Setabense (provincia Catalano-ValencianoProvenzal). Lazaroa 16: 141-158.

Garbarino, J.A., Troncoso, N., Delpiano, P., Carvajal, L. \& Russo, A. (2006) Antioxidant activity analysis for the selection of Rosmarinus officinalis L. Natural Product Communications 1:1123-1128.

Greuter, W., H.M. Burdet \& G. Long (1986) Med-Checklist. 3. Dicotyledones (Convolvulaceae -Labiatae). Geneve \& Berlin.

Guara, M. (2002) Elaboración de un Mapa de Densidades de Flora Singular de la Comunidad Valenciana. Generalitat ValencianaUniversitat de València. Valencia.

Hossain M. B., Rai D. K., Brunton N. P., Martin-Diana A. B. \& Barry-Ryan C. (2010) Characterization of Phenolic Composition in Lamiaceae Spices by LC-ESI-MS/MS. Journal of Agricultural and Food Chemistry 50: 10576-10581.

http://dx.doi.org/10.1021/jf102042g

Kontogianni V.G., Tomic G., Nikolic I., Nerantzaki A.A., Sayyad N., Stosic-Grujicic S., Stojanovic I., Gerothanassis I. P. \& Tzakos A. G. (2013) Phytochemical profile of Rosmarinus officinalis and Salvia officinalis extracts and correlation to their antioxidant and antiproliferative activity. Food Chemistry 136: 120-129.

http://dx.doi.org/10.1016/j.foodchem.2012.07.091

Linares I.B., Arráez-Román D., Herrero M., Ibañez E., Segura-Carretero A. \& Fernandez-Gutierrez A. (2011) Comparison of different extraction procedures for the comprehensive characterization of bioactive phenolic compounds in Rosmarinus officinalis by reversedphase high-performance liquid chromatography with diode array detection coupled to electrospray time-of-flight mass spectrometry. Journal of Chromatography A 1218: 7682-7690.

http://dx.doi.org/10.1016/j.chroma.2011.07.021

Mateu-Andrés, I., Aguilella A., Boisset F., Currás R., Guara M., Laguna E., Marzo A., Puche Ma. F. \& Pedrola J. (2013) Geographical patterns of genetic variation in rosemary (Rosmarinus officinalis) in the Mediterranean basin. Botanical Journal of the Linnean Society 171: 700-712.

http://dx.doi.org/10.1111/boj.12017

Morales, R. (2010) Rosmarinus L. In: Morales R. et al. (eds.). Flora iberica 12: 327-331. Real Jardín Botánico, C.S.I.C., Madrid.

Pau, C. (1891) Notas botánicas a la flora española. Fascículo 4º Escuela Tipográfica del Hospicio. Madrid.

Rivas-Martínez, S. (2007) Mapa de series, geoseries y geopermaseries de vegetación de España. Memoria del Mapa de Vegetación Potencial de España. Parte 1. Itinera Geobotanica 17: 1-436.

Rivas-Martínez, S., Díaz, T. E., Fernánez-González, F., Izco, J., Loidi, J., Lousã, M., \& Penas, A. (2002) Vascular plant communities of Spain and Portugal. Addenda to the syntaxonomical checklist of 2001. Part. I. Itinera Geobotanica, 15: 5-922.

Rosselló J. A., R. Cosín, M., Boscaiu, O., Vicente, I., Martínez \& P. Soriano (2006) Intragenomic diversity and phylogenetic systematics of wild rosemary (Rosmarinus officinalis L. s.1., Lamiaceae) assessed by nuclear ribosomal DNA sequences (ITS). Plant Systematics and Evolution 262: 1-12.

http://dx.doi.org/10.1007/s00606-006-0454-5

Rosselló, J. A. \& Sáez L. (2000) Index Balearicum: An annotated check-list of the vascular plants described from the Balearic Islands. Collectanea Botanica (Barcelona) 25(1): 3-203. 
Rosúa, J.L. (1981) El complejo Rosmarinus eriocalyx-tomentosus en la Península Ibérica. Anales del Jardín Botánico de Madrid 37(2): $587-595$

Rosúa, J.L. (1986) Contribución al estudio del género Rosmarinus L. en el Mediterráneo Occidental. Lagascalia 14(2): $179-187$.

Rosúa, J.L. \& García Granados A. (1987) Analyse des huiles essentielles d'espèces du genre Rosmarinus L. et leur intérêt en tant que caractère taxonomique. Plantes médicinales et phytothérapie 21: 138-143.

Segarra-Moragués J.G. \& Gleiser G. (2009) Isolation and characterization of di and tri nucleotide microsatellite loci in Rosmarinus officinalis (Lamiaceae), using enriched genomic libraries. Conservation Genetics 10: 571-575.

http://dx.doi.org/10.1007/s10592-008-9572-7

Turril, W.B. (1920) The genus Rosmarinus. Kew Bulletin 105-107

Valant-Vetschera K.M., Roitman J.N. \& Wollenweber E. (2003) Chemodiversity of exudate flavonoids in some members of the Lamiaceae. Biochemical Systematics and Ecology 31: 1279-1289.

http://dx.doi.org/10.1016/S0305-1978(03)00037-1

Zaouali, Y. \& Boussard M. (2008) Isozyme markers and volatiles in Tunisian Rosmarinus officinalis L. (Lamiaceae): A comparative analysis of population structure. Biochemical Systematics and Ecolology 36: 11-21.

http://dx.doi.org/10.1016/j.bse.2007.08.005

Ziaková A. \& Brandsteterová E. (2003) Validation of HPLC determination of phenolic acids present in some Lamiaceae family plants. Journal of Liquid Chromatography \& Related Technologies 26: 443-453.

http://dx.doi.org/10.1081/JLC-120017181 